NBER WORKING PAPER SERIES

\title{
TECHNOLOGY AND LABOR REGULATIONS: THEORY AND EVIDENCE
}

\author{
Alberto Alesina \\ Michele Battisti \\ Joseph Zeira \\ Working Paper 20841 \\ http://www.nber.org/papers/w20841
NATIONAL BUREAU OF ECONOMIC RESEARCH
1050 Massachusetts Avenue
Cambridge, MA 02138
January 2015

This paper builds on a previously circulated manuscript with a similar title by Alesina and Zeira. We thank Daron Acemoglu, Olivier Blanchard, Francesco Caselli, Giovanni Di Bartolomeo, Diego Comin, Giorgio di Giorgio, Gene Grossman, Sharon Haddad, Bart Hobijn, Adam Jaffee, Larry Katz, Francis Kramarz, and Chris Pissarides for very helpful comments. Filipe Campante, Giampaolo Lecce, Sarit Weisburd, and Anna Zapesochini provided excellent research assistance. Joseph Zeira thanks the Israel Science Foundation, the Aaron and Michael Chilewich Chair and the Mary Curie Transfer of Knowledge Fellowship of the European Community's 6th Framework Program under contract MTKD-CT-014288 for financial support. Remaining errors are of course ours only. The views expressed herein are those of the authors and do not necessarily reflect the views of the National Bureau of Economic Research.

NBER working papers are circulated for discussion and comment purposes. They have not been peerreviewed or been subject to the review by the NBER Board of Directors that accompanies official NBER publications.

(C) 2015 by Alberto Alesina, Michele Battisti, and Joseph Zeira. All rights reserved. Short sections of text, not to exceed two paragraphs, may be quoted without explicit permission provided that full credit, including $\odot$ notice, is given to the source. 
Technology and Labor Regulations: Theory and Evidence

Alberto Alesina, Michele Battisti, and Joseph Zeira

NBER Working Paper No. 20841

January 2015

JEL No. J31,J50,O33

\section{ABSTRACT}

This paper shows that different labor market policies can lead to differences in technology across sectors in a model of labor saving technologies. Labor market regulations reduce the skill premium and as a result, if technologies are labor saving, countries with more stringent labor regulation, which are binding for low skilled workers, become less technologically advanced in their high-skilled sectors, and more technologically advanced in their low-skilled sectors. We then present data on capital output ratios, on estimated productivity levels and on patent creation, which support the predictions of our model.

Alberto Alesina

Department of Economics

Harvard University

Littauer Center 210

Cambridge, MA 02138

and IGIER

and also NBER

aalesina@harvard.edu

Michele Battisti

Dipartimento di Studi su Diritto, Politica e Socie

Università di Palermo, Piazza Bologni, 8

90134 Palermo, Italy

P IFKHOMEDW JP DOFRP

mbattisti@unipa.it
Joseph Zeira

Department of Economics

The Hebrew University of Jerusalem

Mt. Scopus

Jerusalem 91905

ISRAEL

joseph.zeira@mail.huji.ac.il 


\section{Technology and Labor Regulations: Theory and Evidence}

\section{Introduction}

Countries differ in the technologies they use for production. The most obvious differences are between rich and poor countries, but even within the rich countries there are significant differences. This paper is part of the effort to understand such technology differences across developed countries. It suggests that labor market regulations have a significant effect on technology adoption, where higher labor regulation biases technology toward low-skilled sectors, while lower labor regulation biases technology toward high-skilled sectors. The paper presents a theoretical model that makes this claim and some empirical evidence that supports it.

The standard modeling of technology in macroeconomics assumes that it can be described by a variable that has a positive effect on output for any combination of inputs. The simplest example is a variable that multiplies the aggregate production function. Within this standard modeling, whenever there is technical progress and this variable increases, every country should adopt the new technology. Hence, a theory of cross-country technological differences must depart from this approach in one way or another. One of the early examples to such departure is Parente and Prescott (1978), who introduce costs of technology adoption. This paper assumes instead that technologies are embedded in new machines that replace workers. As a result, adopting a new technology reduces labor costs but increases capital costs, as it requires purchasing machines. Hence, a technology is adopted only if wages are sufficiently high.

We embed this mechanism of technology adoption within a model of two sectors, high-skilled and low-skilled, where the labor market is regulated. We model regulation as unemployment benefits, but it can be viewed more broadly as any welfare policy that supports low income workers. These policies reduce the supply of low-skilled relative to high-skilled and thus lower the skill premium. ${ }^{1}$ As a result, producers in low-skilled sectors face higher wages and choose more low-skill technologies, while producers in high-skilled sectors face lower wages, so they choose less high-skill technologies. Hence, in countries with more stringent labor regulation technology adoption is low-skill biased, while in countries with less stringent labor regulation technology adoption is high-skilled biased.

\footnotetext{
${ }^{1}$ It can be shown that other types of labor regulation, like minimum wages or firing costs, have similar effects.
} 
We test empirically the predictions of the model using several measures of labor market regulation: employment protection legislation, union density, union coverage, namely the percent of workers covered by collective bargaining, and the ratio between the minimum wage and the average wage. We then test how these measures affect a number of variables that should be related to technology adoption. One is the ratio between the amounts of capital in the high and the low-skilled sectors. According to our model this ratio depends positively on technology choice. Another variable related to technology adoption is productivity, of high and low-skilled labor. We use the Caselli and Coleman (2006) calculation of these productivities to test how they are affected by labor regulation. Finally, since there is correlation between the types of technologies adopted by a country and the types of technologies it develops, we use patent data by sectors as a measure of technology bias. The estimation of the effects of the above measures of labor regulation on these three measures of technology choice supports the main claim of the paper. Namely, these tests show that labor regulation tends to make technology more low-skill biased and less high-skill biased.

This paper is related to several lines of research. The first one is the literature on technology adoption, which tries to understand why it differs across countries. As mentioned above, one of the early contributions to this literature is Parente and Prescott (1994). Other papers claim that technology adoption requires some levels of human capital, and the lack of the latter creates hurdles to the process. ${ }^{2}$ Sachs (2000) claims that many technologies are geographically biased, especially in agriculture and health. Our model, in which technologies are embedded in machines that replace workers, is especially related to Champernowne (1963) and Zeira (1998), where high wages induce producers to use machines instead of workers by adopting more technologies. ${ }^{3}$ This approach is actually an extension of a much earlier literature on 'directed technical change.' Some recent papers that use the idea of labor saving technical change for understanding economic growth are Zuleta (2008), Peretto and Seater (2005) and Saint Paul (2006). Applications of this approach to understanding economic fluctuations are Blanchard (1997), Caballero and Hammur (1998) and Beaudry and Collard (2001).

A second line of research, which is related to this paper, is on the relation between technical change and the skill premium. Much of this literature claims that skill biased technical change raises

\footnotetext{
${ }^{2}$ See Galor and Moav (2002) and Zeira (2009) for examples.

${ }^{3}$ Hence, this model lies within the more general approach of 'labor cost induced innovations.' See Acemoglu (2011).
} 
the skill premium. ${ }^{4}$ We suggest instead that the rise of the skill premium and skill-biased technical change in the US could have been the result of a third development, namely deregulation of labor markets. This paper, therefore, raises the possibility of some reverse causality, where higher wage inequality induces skill biased technical change and not the other way around. ${ }^{5}$

A third related literature studies economic differences between Europe and the US. In recent decades continental Europe and the US diverged significantly in their labor market policies. While US labor markets have been deregulated and labor unions were significantly weakened since the 1980s, most West European countries have kept relatively high levels of labor regulation through binding minimum wages, high unemployment benefits, firing costs, and generous welfare policies. According to many economists, these different policies coupled with the effects of the supply shocks of the 1970 s, led to the differences observed in unemployment rates between the US and Western Europe. ${ }^{6}$ The growing differences in labor regulation are well documented in many studies, among them Nickell (1997) and Nickell and Layard (1999). ${ }^{7}$ Thus for example, employers can fire workers in France, Germany and Sweden only with advance notice of 7 to 8 months, while in the USA much shorter time is required. Studies have shown that such differences in labor regulation also led to differences in hours worked and in the skill premium. ${ }^{8}$ Other studies have shown that differences in labor regulation have affected also sector distributions. ${ }^{9}$ O'Mahoney and Van Ark (2003) argue that labor market policies led to substitution of labor by capital in sectors where labor is protected by regulation and wages are higher. ${ }^{10}$ Acemoglu (2003a) and Koeniger and Leonardi (2007), find, in a comparison between the US and Germany, that labor-capital substitution has been larger than what can be explained by changes in factor prices alone. Our paper, which raises the possibility of differences in technology, can explain this finding, as capital-labor substitution is intensified by technology choice.

\footnotetext{
${ }^{4}$ Much of this literature focuses on the US. See Davis and Haltwinger (1991), Katz and Murphy (1992), Bound and Johnson (1992), Juhn, Murphy, and Pierce (1993), Berman, Bound and Grilliches (1994), Greenwood and Yorukoglu (1997), Acemoglu (1998, 2003), and Berman, Bound and Machin (1998).

${ }_{6}^{5}$ This possibility is also raised in Koeniger and Leonardi (2007).

6 The effect of such labor institutions and macroeconomic shocks on persistent unemployment is analyzed by Blanchard and Wolfers (2000), Lazear (1990) and Blanchard, Cohen and Nouveau (2005). See also Blau and Kahn (1996, 2002), Freeman and Katz (1995), Saint-Paul (2004), and Ljungqvist and Sargent (2006).

${ }^{7} \mathrm{We}$ do not investigate what led to these differences between the US and Europe. Discussions on differences in culture and in attitudes toward welfare policies appear in Alesina et al (2010) and in Alesina and Glaeser (2004).

${ }^{8}$ For effects of regulation on hours worked, see Prescott (2004) Blanchard (2004), Alesina, Glaeser and Sacerdote (2005) and Rogerson (2007). For the effect of regulation on the skill premium see Katz and Murphy (1992), Blau and Khan (1996, 2002) and Gottschalk and Smeeding (1997).

${ }^{9}$ See Davis and Henrekson (1997, 1999, 2005a) and Bertrand and Kramarz (2002).

${ }^{10}$ See also Davis and Henrekson (2005b), Freeman and Schettkat (2005) and Ngai and Pissarides (2009). See also Autor, Kerr and Kugler (2007) and Beaudry and Green (2003).
} 
Acemoglu (2003) and Koeniger and Leonardi (2007) offer a different explanation to labor-capital substitution through distortions to investment by labor regulation.

The paper is organized as follows. Section 2 presents the basic model. Section 3 derives the basic results of the model while Section 4 presents some additional results. Section 5 describes the empirical strategy. Section 6 presents empirical results with respect to capital ratios, Section 7 with respect to productivities and Section 8 with respect to patent creation. Section 9 concludes. The Appendix contains mathematical derivations and sources of data.

\section{A Model of Technology and Labor Regulation}

Consider an economy with a continuum of individuals of size 1. People supply one unit of labor each and can work as high-skilled or low-skilled if educated, or only as low-skilled if they are not. ${ }^{11}$ Denote by $L_{n}$ the share of low-skilled and by $L_{s}$ the share of high-skilled, so that: $L_{n}+L_{s}=1$. While high and low skilled differ by the sector they can work in, all workers, high and low skilled, differ by personal efficiency $e$, which is assumed to be random, to be distributed uniformly between zero and 1 , and to be independent of skill. There is a single final good in the economy, used for consumption and for investment. People derive utility from consumption of this final good:

$$
\ln (c) \text {. }
$$

The single final good is produced by two intermediate goods, the high skilled good $S$ and the low skilled good $N$, using the following production function:

$$
Y=S^{\alpha} N^{1-\alpha} \text {. }
$$

Namely, it is assumed for simplicity that the elasticity of substitution between the two intermediate goods is 1 . The high-skilled good is produced by infinite tasks, or infinite intermediate goods $i \in[0,1]$, according to the following Cobb-Douglas production function:

$$
\ln S=a+\int_{0}^{1} \ln s(i) d i
$$

Each $i$ can be produced by one of two potential technologies. One is manual, where a unit of $i$ is produced by 1 efficiency unit of high-skilled labor. The second technology is industrial and it produces one unit of $i$ by a machine of size $k(i)$. Capital, namely machines, depreciates fully within 1 period. Invention of a new technology, which is imbedded in a machine, is assumed to be costless.

\footnotetext{
${ }^{11}$ This assumption only warrants that skilled wages are always higher than or equal to unskilled wages.
} 
This assumption means that once producers want to adopt an industrial technology, it is available, and that the only cost of industrialization is the cost of the machine. Assume that this cost, $k(i)$, is rising with $i$. To simplify the analytical solution we use the following specification:

$$
k(i)=\frac{1}{1-i} .
$$

The low-skilled good is produced by a similar production function:

$$
\ln N=a+\int_{0}^{1} \ln n(i) d i .
$$

Similarly, each low-skilled intermediate good can be produced either by one efficiency unit of lowskilled labor or by a machine of size $k(i)$, where the function $k$ is the same as in (4). ${ }^{12}$

The economy is open to capital mobility and is small, so that the world interest rate is taken as given and is equal to $r$. The gross interest rate is $R=1+r$, which is equal to the interest rate plus the rate of depreciation. The economy trades only in the final good, and not in high and low skilled, and intermediate goods. Note that in the static setup of the model, domestic agents do not save and capital is fully financed from abroad. This has no effect on the main results. ${ }^{13}$

There is labor market regulation, where jobless workers receive unemployment compensation equal to a fraction $v$ of the wage of an efficiency unit of unskilled labor. This unemployment benefit is financed by a tax of rate $t$ on all income, including transfer payments, that keeps the budget balanced. This regulation is similar to other welfare policies that support people who do not fare well in the labor market. We do not model why there is no private insurance to labor risk and just assume that it is publicly supplied. The unemployment benefits lead the least efficient workers to drop from the labor market, and low-skilled do it more than high-skilled. Hence, the supply of low-skilled falls by more than the supply of high-skilled, which lowers the skill premium.

\section{Equilibrium with Endogenous Technologies}

\subsection{Technology Adoption}

Denote by $w_{n}$ the gross wage of one efficiency unit of low-skill workers, and $w_{s}$ the wage of one efficiency unit of high-skill workers. Then, a high-skill intermediate good is produced by machines, if:

\footnotetext{
12 This symmetry between the two sectors and the other specific assumptions of the model, like logarithmic utility and the elasticity of substitution 1 between skilled and unskilled goods, do not affect the qualitative results of the model.

${ }^{13}$ Alternatively, we can assume that agents live in a non-overlapping-generations economy, and each leaves a bequest to her offspring, so that the bequest is domestic saving.
} 


$$
w_{s} \geq R k(i)=\frac{R}{1-i} \text {. }
$$

Hence, all high-skill intermediate goods $i \leq f_{s}$ are produced by machines, where the technological frontier for high-skill workers, $f_{s}$, is determined by:

$$
1-f_{s}=\frac{R}{w_{s}} .
$$

Note that if $w_{s}<R$ then $f_{s}=0$ and there is no industrialization in the high-skill sector. Similarly, industrialization in the low-skill sector is chosen in tasks $\left[0, f_{n}\right]$, where:

$$
1-f_{n}=\frac{R}{w_{n}},
$$

or $f_{n}=0$ if $w_{n}<R$.

Hence, the low cost machines replace workers in the corresponding jobs, while workers in the other jobs remain at work, as the machines that can replace them are too expensive. Note that although technical change substitutes labor by capital, it is also highly complementary to labor. Increasing $f_{s}$ or $f_{n}$ eliminates labor from some jobs, but the workers who crowd the remaining jobs, $\left[f_{s}, 1\right]$ and $\left[f_{n}, 1\right]$, become more productive, since they work with more machines. For an intuitive example, think of an accountant, who uses a computer for performing calculations that she used to do manually before, and as a result becomes more productive.

Let $P_{S}$ be the price of the high-skill good, and $p_{s}(i)$ be the price of the intermediate good $i$ in the production of $S$. On the demand side we can use the first order conditions of profit maximization of producers of the final good, the high-skill and the low-skill good. On the supply side prices of intermediate goods in the two sectors are equal to production costs, due to free entry and constant returns to scale. Hence:

$$
p_{s}(i)= \begin{cases}\frac{R}{1-i} & \text { if } \quad i \leq f_{s} \\ w_{s} & \text { if } \quad i>f_{s} .\end{cases}
$$

Prices of intermediate goods in the unskilled sector are similar. Equating demand and supply prices leads, as shown in appendix 1, to the following equilibrium condition:

$$
\alpha f_{s}+(1-\alpha) f_{n}=a+\varepsilon-\ln R,
$$


where $\varepsilon=\alpha \ln \alpha+(1-\alpha) \ln (1-\alpha)<0$. We call equation (9) the "goods markets equilibrium condition." It describes a trade-off between the two technology frontiers. This condition holds only for non-negative $f_{s}$ and $f_{n}$.

Denote the wage ratio between the high-skill and low-skill by $I$, which is a measure of the skill premium. From conditions (6) and (7) we get:

$$
I=\frac{w_{s}}{w_{n}}=\frac{\frac{R}{1-f_{s}}}{\frac{R}{1-f_{n}}}=\frac{1-f_{n}}{1-f_{s}} .
$$

Hence, we derive the following "industrialization constraint":

$$
f_{n}=1-I+I f_{s} .
$$

Together, equations (9) and (10) determine the equilibrium technologies and the wages in each sector given the wage ratio $I$, as shown in Figure 4. The $\mathbf{G}$ curve describes the goods market equilibrium condition (9), while the $\mathbf{L}$ curve describes the industrialization constraint (10). The intersection of the two curves determines the equilibrium, including the levels of technology in the two sectors.

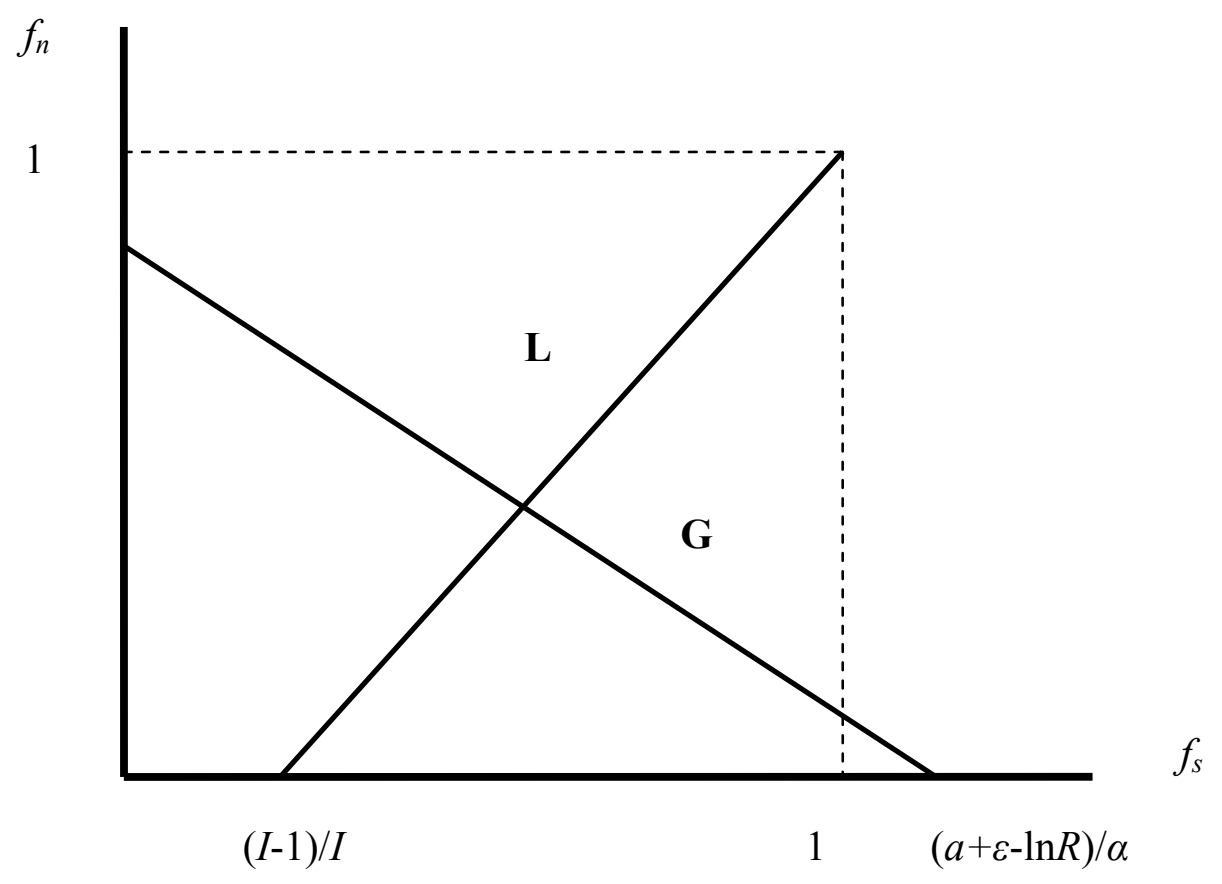

$\underline{\text { Figure 1: Determination of Technology Frontiers }}$ 
The equilibrium described by Figure 1 can be easily calculated. Since high-skill workers can always switch and work as low-skill, the wage ratio $I$ satisfies: $1 \leq I<\infty$. From equations (9) and (10) we get that the high-skill technology frontier is:

$$
f_{s}=1-\frac{1+\ln R-\varepsilon-a}{\alpha+(1-\alpha) I} .
$$

The technology frontier in the low-skill sector is:

$$
f_{n}=1-I \frac{1+\ln R-\varepsilon-a}{\alpha+(1-\alpha) I} .
$$

From these two equations and from Figure 1 it follows that a sufficient condition for $f_{n}$ and $f_{s}$ to be between 0 and 1 for all $I>1$ is that the productivity $a$ satisfies:

$$
\ln R-\varepsilon+1 \geq a \geq \ln R-\varepsilon+\alpha .
$$

From here on we assume that this condition holds.

As the wage ratio $I$ increases, the curve $\mathbf{L}$ shifts down, reducing $f_{n}$ and increasing $f_{s}$. . Hence the skill premium induces higher technology choice in the high-skill sector, but leads to a lower technology choice in the low-skill sector. As for wages, equations (6) and (7) imply that the wage of high-skill workers rises and the wage of low-skill workers declines. If instead of $I$, productivity $a$ changes, higher productivity shifts the curve $\mathbf{G}$ instead. Hence, a country with higher productivity chooses more technologies in both sectors, high and low-skilled.

As shown above, reduction of the skill premium raises wages of low-skilled, but also lowers wages of high-skilled. In other words, even if the social policies aim only at raising the wages of unskilled workers, they end up in lowering the wages of skilled workers. The reason is that since the production function (2) is CRS, there is a complementarity between high and low skill goods in production of the final good. Raising wages of unskilled reduces their input and the production of the low-skill good, which lowers the marginal productivity of the high-skill good.

\subsection{The Equilibrium Wage Ratio}

A worker chooses to work only if her earnings exceed the welfare payment. Hence a low-skilled goes to work only if: $e w_{n}(1-t) \geq v w_{n}(1-t)$, namely if $e \geq v$. Hence, the low-skill rate of unemployment is:

$$
u_{n}=v .
$$

A high-skilled supplies labor if: $e w_{s}(1-t) \geq v w_{n}(1-t)$. Hence, the high-skill rate of unemployment is: 


$$
u_{s}=\frac{v}{I}
$$

Note that this is voluntary unemployment.

We next derive the wage ratio $I$. For this we first present the labor market clearing conditions for high and low skilled. These equilibrium conditions are derived in Appendix 2 by equating supplies and demands for labor in terms of efficiency units. The clearing condition for high-skilled labor is:

$$
\frac{L_{s}}{2}\left(1-\frac{v^{2}}{I^{2}}\right)=\frac{\alpha R Y}{w_{s}^{2}},
$$

and for low-skill labor is:

$$
\frac{L_{n}}{2}\left(1-v^{2}\right)=\frac{(1-\alpha) R Y}{w_{n}^{2}} .
$$

From these two conditions we derive the equilibrium value of the wage ratio $I$ :

$$
I^{2}=\frac{\alpha}{1-\alpha} \frac{L_{n}}{L_{s}}\left(1-v^{2}\right)+v^{2}
$$

We next note that the following condition must always hold:

$$
\alpha L_{n} /\left[L_{s}(1-\alpha)\right] \geq 1 .
$$

This is a result of the assumption that high-skill workers can always work in the low-skill sector. If this condition does not hold, the wage ratio is lower than 1 and as a result high-skill workers turn to low-skill jobs, which pay a higher wage. That drives the wage ratio up to 1 , by reducing the actual $L_{s}$ and increasing $L_{n}$, which restores this condition. Thus, condition (19) implies that the wage ratio is greater or equal to 1 , and also that it depends negatively on the degree of labor market regulation $v$. Finally note that condition (19) is equivalent to $L_{s} \leq \alpha$.

\subsection{The Effect of Unemployment Compensation}

A country with a higher unemployment compensation $v$ has a lower wage ratio $I$. As shown above, this shifts the $\mathbf{L}$ curve in Figure 1 to the left and as a result this country becomes less mechanized in the high-skill sector, namely $f_{s}$ is lower, and more mechanized in the low-skill sector, namely $f_{n}$ is higher. Furthermore, $w_{s}$ is lower and $w_{n}$ is higher. The effect of labor regulation on the wage ratio works through the effective supplies of high and low skill labor, since unemployment compensation reduces the supply of low-skilled by more than the supply of high-skilled.

Note, that the effect of labor regulation $v$ on the wage ratio $I$ is amplified by technology choice. A decline in $I$ due to labor regulation reduces technology in the high-skilled sector and increases it in 
the low-skill sector. This further lowers the high-skill wage $R /\left(1-f_{s}\right)$ and further raises the low-skill wage $R /\left(1-f_{n}\right)$. Hence, the skill premium in this economy declines not only as a result of more regulation, but also as a result of the interaction with technology adoption. This amplification is manifested in the square of the wage ratio in equation (18). ${ }^{14}$

\section{Additional Results}

In this section we further describe the equilibrium, by calculating the levels of aggregate output, unemployment, the tax rate, welfare, and capital ratios.

\subsection{Employment, Output and Fiscal Policy}

The aggregate unemployment rate is:

$$
u=L_{n} v+L_{s} \frac{v}{I}=v\left[1-L_{s}\left(1-\frac{1}{I}\right)\right]
$$

Hence, labor regulation increases the rate of unemployment. Aggregate output can be derived from the labor market equilibrium condition (16) and is equal to:

$$
Y=\frac{L_{s}}{2 \alpha R}\left(1-\frac{v^{2}}{I^{2}}\right) w_{s}^{2} .
$$

Note that (20) describes output per capita as well. Equation (20) indicates that output per capita is affected by labor regulation $v$ in three ways, directly, through $I$ and through $w_{s}$. An increase in $v$ reduces the skill premium $I$ and also reduces the skilled wage $w_{s}$. Hence, (20) implies that labor regulation reduces output.

We next examine how the tax rate is affected by regulation. The balanced budget requirement amounts to equalization of taxes to unemployment benefits. Since income in this economy is from labor only, as capital is financed from abroad, the government gets revenues from labor only, including subsidies. As a result the fiscal policy balanced budget constraint is: ${ }^{15}$

$$
\begin{aligned}
\left(L_{n} v+L_{s} v / I\right) v w_{n} & =t\left[L_{s} w_{s} \int_{v / I}^{1} e d e+L_{s} \frac{v}{I} v w_{n}+L_{n} w_{n} \int_{v}^{1} e d e+L_{n} v^{2} w_{n}\right]= \\
& =\frac{t}{2}\left[L_{s} w_{s}\left(1+\frac{v^{2}}{I^{2}}\right)+L_{n} w_{n}\left(1+v^{2}\right)\right] .
\end{aligned}
$$

\footnotetext{
${ }^{14}$ This amplification effect has already been noticed by Koeniger and Leonardi (2007).

${ }^{15}$ If income includes capital income the results are not affected at all.
} 
If $v$ is higher, both the unemployment rate and the compensation per unemployed are higher, so that the overall compensation, on the left hand side of (21), is higher. Since income is lower, the tax rate must be higher as well.

\subsection{Welfare}

As shown above, labor regulation reduces output and increases the tax rate but it creates insurance against low efficiency, so that the optimal amount of regulation might not be equal to zero. Our model does not explicitly model the adverse selection that usually leads to market failure of private insurance to supply labor risk. It just assumes that such insurance is publicly supplied. Nevertheless, our model enables us to measure welfare as the ex-ante expected utility before efficiency is revealed. ${ }^{16}$ These exante utilities are actually the average utilities of high and low skilled workers. Since a person consumes all her disposable income, the expected utility of low-skilled is:

$$
U_{n}=\int_{0}^{v} \ln \left[v w_{n}(1-t)\right] d e+\int_{v}^{1} \ln \left[e w_{n}(1-t)\right] d e=\ln w_{n}+\ln (1-t)+v-1 .
$$

Similarly the expected utility of a high-skill $\mathrm{w}$ is:

$$
U_{s}=\ln w_{s}+\ln (1-t)+\frac{v}{I}-1
$$

The effect of increasing $v$ is therefore mixed. It has a direct positive effect on welfare, due to reducing the probability of poverty for both types. But it raises tax payments, which reduces welfare. Also, increasing $v$ raises the low-skill wage, but lowers the high-skill wage. Hence it has different effects on the two types of workers. Thus, such policy is more appealing to low-skilled than to high-skilled workers, as expected.

Aapplying equal weights to all individuals we get that average ex-ante expected welfare is:

$$
\operatorname{AVG}(U)=L_{n} U_{n}+L_{s} U_{s}=\left(1-L_{s}\right) U_{n}+L_{s} U_{s} .
$$

A full theoretical examination of the effect of labor regulation on welfare is complicated, due to the opposing effects described above, but we show in Appendix 3 that the $d[\operatorname{AVG}(U)] / d v$ is positive at $v=0$. Hence, the optimal level of regulation, which maximizes the average ex-ante expected welfare, is always positive. We can also calculate the optimal level of regulation $v$ and interestingly we find that it does not change much with the parameters of the model. ${ }^{17}$

\footnotetext{
${ }^{16}$ We can think of this as evaluating social welfare behind a veil of ignorance or we can think of embedding our static model in a non-overlapping generation structure in which every period a new identical generation is born and policy is set before individuals become adults and learn about their efficiency.

${ }^{17}$ These results can be supplied by request.
} 


\section{$\underline{4.3 \text { Capital across Sectors }}$}

We next examine the amounts of capital in the two sectors, as a preparation to our empirical analysis. The amount of capital in the high-skilled sector is:

$$
K_{s}=\int_{0}^{f_{s}} \frac{s(i)}{1-i} d i=f_{s} \frac{P_{S} S}{R}=\alpha f_{s} \frac{Y}{R} .
$$

Capital in the low-skilled sector is:

$$
K_{n}=\int_{0}^{f_{n}} \frac{n(i)}{1-i} d i=f_{n} \frac{P_{N} N}{R}=(1-\alpha) f_{n} \frac{Y}{R} .
$$

Note that the capital to output ratio in each sector varies with technology. ${ }^{18}$ From (25) and (26) we get that the ratio of the amounts of capital in the two sectors is equal to:

$$
\frac{K_{s}}{K_{n}}=\frac{\alpha}{1-\alpha} \frac{f_{s}}{f_{n}} .
$$

Equation (27) implies that this ratio should be positively related to the wage ratio and negatively related to labor regulation.

In Appendix 4 we show that in a standard model without technology adoption, the effect of the wage ratio and of labor regulation on this ratio is zero. To further clarify this point note that labor regulation raises the wage premium and also reduces the input of low-skilled workers. The rising wage makes low-skilled labor more expensive, and so producers substitute labor by capital in the low-skill sector. But the reduction in low-skill workers has an opposite effect on capital, due to complementarity between the two factors. As Appendix 4 shows, in the standard model the two opposing effects cancel out each other. In this model substitution dominates, as shown by equation (27). The reason is that substitution between labor and capital is amplified by technology adoption. These two opposing predictions in the two models lead us to examine the issue empirically in Section 6.

\subsection{Additional Results}

This model has some additional results, which mainly examine the robustness of its main results. First, we examine what happens if the choice of skill is endogenous and show that the main results of the paper still hold. Another extension examines what happens if the minimum income is not indexed to the wage of low-skilled, but to a composite of high and low-skilled wages. Again, this extension yields the same main results. We also examine two alternative labor regulations, minimum wage and firing

\footnotetext{
${ }^{18}$ Note that the aggregate capital output ratio is equal to $[a+\varepsilon-\log R] / R$, as implied by equations (19), (20) and (9). Hence, the aggregate capital output ratio is equal across countries in this model. It differs only with respect to sectors.
} 
costs, and show that these regulations yield the same basic results as in the benchmark model. All these additional results are available upon request.

\section{Empirical Strategy}

In our empirical analysis we examine the effect of variables that measure labor market regulation on variables related to technology adoption, both across countries and over time. We use four variables to measure labor regulation. The first is an index of employment protection legislation, which is denoted EPL. The second is union density, which measures the share of unionized workers and is denoted UD. The third is union coverage, which measures the share of workers covered by collective bargaining and is denoted UC. The fourth is the ratio of minimum wage to average wage and is denoted MW_AW. The variables we use to represent technology are three. The first is the ratio between capital in high-skilled sectors and capital in low-skilled sectors, which we denote KRATIO. The second is productivity, namely productivity of high-skilled labor and productivity of low-skilled labor, which are denoted AS and AL respectively. The third variable is patent production per capita in a country in high-skilled sectors and in low-skilled sectors. These are denoted HSPAT and LSPAT respectively. Table A.1 in Appendix 5 lists the data sources for the various variables used in the empirical analysis.

We next examine these variables in more detail, starting with labor market variables. The variable EPL, employment protection legislation, which is calculated in OECD (2013), measures procedures and costs involved in laying-off individuals or groups of workers. More specifically, it is a score constructed from a survey disseminated among experts with 21 questions in three areas: protection of workers against individual layoff, regulation of temporary employment, and specific requirements for collective layoffs. The results of the survey are processed to a score on a scale of $0-6$, where higher values represent stricter regulation. The variable UD, union density, measures the share of union members among workers and is taken from Visser (2011). It should be correlated with labor regulation for two reasons. First, if labor unions are stronger, they apply more pressure on the government to regulate the labor market and to choose policies that reduce wage inequality. ${ }^{19}$ Second, the government can also affect union strength by its labor market policies, both as an employer and as a labor market regulator. Thus, labor market regulation and union density should be positively correlated. Union coverage, UC, measures the share of workers whose wages are covered by collective

\footnotetext{
${ }^{19}$ For a discussion of how unions promote policies reduce wage inequality, especially in Europe, see Alesina and Glaeser (2004), Alesina, Di Tella and McCulloch (2004), Blau and Khan (2002) and also Kramarz (2007).
} 
bargaining. This measure is of course not lower than union density and in some cases, like in France, it is much higher. We apply it to some of the tests, using Visser (2011) as well, and find that it leads to similar results as union density. This is not surprising as the correlation between union density and union coverage is 0.54 . The fourth variable we use is $\mathrm{MW}$ AW, the ratio of the minimum wage to the average wage, which is taken from ILO (2013). This variable is available for a shorter time span than the other variables, from 1995 only and for many countries even from the 2000s. As a result this variable happens to be less significant in many of the regressions and we use it less as well. Table 1 presents the descriptive statistics of the variables that measure labor regulation. Since the data sets of the various variables cover different sets of countries and years, we calculate the correlations between each two variables using the largest common set of observations for the two variables.

[Insert Table 1 here]

The variables that measure labor regulation change significantly across countries. In 2000, union density was less than 20 percent in France, USA, Spain, and Korea, while it was around 80 percent in Sweden, Finland, Denmark and China. Union coverage however was much higher in France than union density and was on average 80 percent over the period, and was high in Spain as well, at 78 percent. In the USA union coverage was very similar to union density. It was 22 percent on average, and with a declining trend, so that it reached 13 percent in 2011. In 2000 the score for employment protection legislation, EPL, was close to 0 for the USA and lower than 1.5 for Canada, UK, New Zealand, Ireland and Australia. At the same year it was around 3 for Greece and the Netherlands and it was close to 5 in Portugal. The ratio between the minimum wage and the average wage was also quite diverse in 2000, going from 0.2 in Korea and Mexico to close to 0.6 in France, Australia, the Netherlands and New Zealand. ${ }^{20}$ Labor regulation not only differs across countries, but experiences some changes over time as well. One of the main ones has been a significant deregulation of labor markets in the US, while European countries experienced less deregulation.

As mentioned above in this section, we test for the effects of the labor regulation measures on variables that should be correlated with technology. For each test we run both a standard pooled

\footnotetext{
${ }^{20}$ We have removed from the data 16 observations of MW_AW, in which the minimum wage exceeds the average wage. Of these observations 11 are in the Philippines, where this ratio is around 1.3 and is obviously measured badly or indicates no enforcement of minimum wage. Another case is Guatemala, for which we have only one observation in one year of 1.09. The rest of the 16 observations are in Iran and Paraguay. Since we don't have data on the main explanatory variables for these countries, the data screening does not affect our analysis much.
} 
regression and a panel regression with country fixed effects to add robustness. The importance of the panel regression with fixed effects is that it can show that even if we control for country specific effects, the labor regulation variables have significant effects.

\section{Effect of Labor Regulation on Capital Ratios}

Our empirical analysis begins with a test of the empirical implication derived in Sub-Section 4.3, namely that the ratio of the amounts of capital in the high-skilled and low-skilled sectors should fall if labor market regulation increases. The amounts of capital in low-skill and high-skill sectors are derived from two sources. First, we get the quantities of capital per sector from the EU KLEM database, in O'Mahony and Timmer (2009). This data set contains information on sectors according to the international classification ISIC revision 3. The data contains capital amounts for 56 two digit industries. We classify these sectors to high-skilled and low-skilled following Robinson, Stokes, Stuivenwold and van Ark (2003). They classify sectors to 4 categories of skill, namely low-skilled, low-intermediate-skilled, high-intermediate-skilled and high-skilled. Using data on the distribution of skills in sectors, they create three separate taxonomies of sectors by skill, one based on data from the US and the UK, one based on Eurostat data of all EU countries and one on Eurostat data in the 7 largest EU countries. As the three taxonomies are quite similar, they form a final taxonomy that

summarizes all three. ${ }^{21}$ We use this classification, but group together the high and high-intermediate skill sectors together into high-skilled and the low and low-intermediate skilled into low-skilled. For each country we aggregate the amounts of capital for the high-skilled sectors and for the low-skilled sector and then calculate their ratio, which is denoted KRATIO.

The empirical tests below are regressions of the annual change in KRATIO, namely $\triangle \mathrm{KRATIO}$, on the measures of labor regulation. The reason we run tests on annual changes and not on the level of KRATIO, is the following. Our model is static for simplification, so it assumes that all technologies for adoption are available. But in reality such technologies are invented gradually over time. Thus the variable KRATIO should rise over time, faster for countries with low labor regulation and slower for countries with high labor regulation. This is what is tested below in Table 2 .

[Insert Table 2 here]

${ }^{21}$ Table II.9a in the chapter. 
All the regressions in Table 2 support our model and show that labor regulation is negatively correlated with the growth of capital ratio between the high and low-skilled sectors. Regression 1 shows that employment protection regulation has a significant negative effect and regression 2 shows that if we add to the regression union density, both variables have significant negative effects. Note that we add a dummy variable to control for the unification of Germany in 1991, since capital ratios differ in Germany before and after unification. Adding the ratio of minimum wage to average wage in regression 3 does not improve the estimation. This variable itself has a positive effect, which is opposite to expected, but this can be explained by the negative correlation between minimum wage and EPL, as shown in Table 1. Adding MW_AW increases the negative effect of union density, but reduces significantly the number of countries and observations, as data on minimum wage are available only for recent years. That is also the reason why the dummy for German Unification is not relevant for this regression. Adding union coverage, UC, to the two main variables, EPL and UD, does not change the results much. The regression coefficients of EPL and UD remain negative and significant at $1 \%$, while union coverage is insignificant, presumably due to the correlation of UC and UD. This regression is not reported in Table 2. The panel fixed effects regressions, 4 to 6, paint a similar picture. The employment protection legislation EPL has a negative effect, of similar size, in all three regressions, and all are significant at 1\%. Union density has a negative effect, significant at $10 \%$, and only when minimum wage is added it becomes insignificant.

The two main labor regulation variables, EPL and UD, not only have a negative effect on $\triangle \mathrm{KRATIO}$, but this effect is quite big. To see this, take for example the second panel regression, which includes the two variables together. The coefficient of EPL in this regression is -0.08. EPL fluctuates between 0.25 and 5 . Hence this variable can explain variability between 0.02 and 0.4 . Since $\triangle$ KRATIO fluctuates between -0.5 and 0.13 , EPL can account to almost half of these fluctuations. The coefficient of UD in that regression is -0.113 , and UD fluctuates between 0.06 and 0.99 . Hence fluctuations in UD can account for differences in $\triangle \mathrm{KRATIO}$ of the order of 0.1 , which amounts to 17 percent of the amplitude of this variable. We therefore conclude that labor regulation is correlated with the increase over time in the KRATIO variable and can account for a large part of its variation.

\section{Effects of Labor Regulation on Productivities}

Our model predicts that changes in labor regulation affect the choice of technology in a country both in high-skill and in low-skill sectors. The best possible empirical strategy to test this claim directly is 
to use data on technology adoption, but such data are not comprehensively available. Recently, Comin and Hobijn (2004, 2006, 2010) and Comin and Mestieri (2013) began to collect such data. But these data are still insufficient for estimating our model, mainly because the number of technologies in this data set that can be easily classified between high-skill and low-skill sectors is not sufficiently large. We therefore turn in this section to a measure that is related to technology, namely productivity or efficiency. In general, if the high-skill sector adopts more technologies, it should have higher productivity, and the same holds for the low-skill sector. This is true especially in our model. If the high-skill sector adopts more technologies, it uses machines for more tasks, which makes the workers in the remaining tasks more productive.

To obtain data on high-skilled and low-skilled productivities we use a method developed by Caselli and Coleman (2006). They assume the following production function:

$$
Y=K^{\alpha}\left[\left(A_{n} L_{n}\right)^{\sigma}+\left(A_{s} L_{s}\right)^{\sigma}\right]^{(1-\alpha) / \sigma},
$$

where $A_{n}$ is productivity of low-skilled workers, $L_{n}$ is the amount of low-skilled workers, and $A_{s}$ and $L_{s}$ are productivity and quantity of high-skilled workers, respectively. Imposing first order conditions and using data on inputs and wage levels Caselli and Coleman (2006) calculate the levels of productivity for the two types of labor for 52 countries in 1988. We extend the calculation of these productivity levels for more periods of time. The data needed for this calculation is output per worker, capital per worker, share of low skilled labor and share of skilled labor in total labor, the skill-premium and the values of $\alpha$ and $\sigma$. The data on output and capital per worker are taken from the new PWT 8, see Feenstra, Inklaar and Timmer (2013). The data on skill premia are taken from Psacharopoulos (1994). The data on the shares of high and low skilled in the population are from Barro and Lee (2010). We follow Caselli and Coleman (2006) in defining high skilled as workers with secondary education and above. Since the Barro and Lee (2010) data set reports on education attainment only at 5 years' intervals, it reduces significantly the number of periods of time for which we can measure productivities. $^{22}$ To overcome this problem we compute from the Barro and Lee data set annual figures on education attainment by interpolation. This can be justified among other things by the very gradual changes in education attainment over time. We run below regressions for the original data, of 5 years intervals, and for the annual extended data as well and report them separately. As shown below, the results are not affected significantly by the extension to annual data, so most of the regressions use the

\footnotetext{
${ }^{22}$ All other variables used for the calculation of productivities and for the regressions are available at annual frequency.
} 
extended data. As for the values of $\alpha$ and $\sigma$, we use the calibration of Caselli and Coleman (2006) for which $\alpha$ is 0.35 and $\sigma$ is 1.4 .

In Tables 3 and 4 we examine how these high-skill and low-skill productivities are affected by labor regulation. Table 3 focuses on the effect on productivity of high-skill workers, AS, while Table 4 refers to low-skilled productivity, AN. In both tests we use the natural logarithm of these two productivities. In some of the tests we also include a time trend to capture the process of global technical change, which should also affect productivity that is supposed to grow gradually. While the data on capital ratios limited us to OECD countries only, we can calculate productivities for a larger set of countries. Since our main claim focuses on differences within developed economies, we present in Tables 3 and 4 only regressions that include the OECD countries. The regressions over a larger set of countries yield very similar results. Note that this is only expanding the number of countries from 23 to 30 , as most available data are from the OECD countries anyway.

[Insert Table 3 here]

The first two regressions in Table 3 are pooled and the others are Panel regressions with country fixed effects. The first regression is with less periods of time and the second is with the extended data, as explained above. Both regressions have similar results. The effect of employment protection legislation EPL is negative and significant. The same result holds when we move from pooled regression to country fixed effects in column 3. The negative effect of EPL on high-skilled productivity is even higher. Adding union density in regression 4 does not change much the effect of EPL, and the effect of UD is negative as well. This addition though increases significantly the 'within $\mathrm{R}^{2}$ ' When we add in regression 5 union coverage, it has no significant effect, but it keeps the effects of EPL and UD almost unchanged. In regression 6 we add the time trend, which comes out positive and significant and reduces the negative effects of EPL and UD. Despite the reduction in their size, the effects of both variables, EPL and UD, remain negative and significant. Finally, adding the minimum wages variable, MW_AW, weakens the regression significantly. The $\mathrm{R}^{2}$ declines from 0.57 to 0.41 , EPL changes sign and the significance of all variables declines. Note that adding minimum wages also reduces the number of observations significantly.

The effect of EPL and UD on high-skilled productivity AS is not only negative and significant but also has a considerable size. We focus on regression 4, a panel regression with both EPL and UD 
as explanatory variables. The coefficient of EPL is -0.4 and since this variable fluctuates between 0.25 and 5 it can account for changes in $\ln (\mathrm{AS})$ of a range of 1.9. Since $\ln (\mathrm{AS})$ fluctuates between 1 and 7 , EPL can account to around a third of this variability. The coefficient of UD in this regression is -1.8 and since this variable changes from close to 0 up to 1 , this variable can account for 1.8 of the variability of $\ln (\mathrm{AS})$, which is also around a third. Hence, EPL and UD account together to two thirds of the variation in high-skilled productivity. This estimate shows that labor market regulation reduces productivity in the high-skill sector and accounts for much of its variability.

[Insert Table 4 here]

Table 4 examines the effects of labor market regulation on the productivity of high-skilled labor AS. While most economic models would predict that stronger labor regulation reduces productivity, Table 4 shows that in the low-skill sector, labor regulation tends to increase productivity. The first three regressions in Table 4 are pooled, while the last four are panel regressions with country fixed effects, which yield similar results. Regressions 1 and 2 show that when moving from the limited data to the extended data the results remain similar: EPL has a positive and significant effect on lowskill productivity. Regression 3 shows that adding the trend to the pooled regression does not change this result, but interestingly the trend is negatively correlated with the productivity of low-skilled. In the panel regressions the effect of EPL is positive, significant and larger. Regression 5 adds union density, which also has a positive significant effect, and keeps the positive effect of EPL unchanged. When union coverage UC is added in regression 6, it has an insignificant effect, but the effects of EPL and UD remain the same as without it. Regression 7 adds the trend, which is significantly negative, as in the pooled regression, but it makes all other variables insignificant. This could be the result of declining labor regulation over time, so that it is partly captured by the trend variable.

To estimate the size of the effect of labor regulation on low-skill productivity we use regression 5 in Table 4, which is a panel regression with the two main variables EPL and UD. The productivity variable $\ln (\mathrm{AS})$ fluctuates significantly between -39 and 48 due to some outliers, so we turn to standard deviations instead of extreme values. The coefficient of EPL in this regression is 2.3 and since its standard deviation is 0.85 , it can account for changes of size 2. The coefficient of EPL is 1.5 and since its standard deviation is 0.2 , it can account for changes of size 0.3 . Since the standard 
deviation of $\ln (\mathrm{AS})$ is 3.17 the two labor regulation variables can explain much of the variation in lowskilled productivity as well.

Finally we should note that there are two mechanisms that can cause a positive effect of labor regulation on low-skilled productivity. The first one operates through technology adoption as predicted in the paper. Labor regulation increases the use of machinery and automation in the low-skilled sector and thus increases productivity in this sector. The second mechanism is self-selection of workers, where those who remain on the job, when labor regulation reduces the number of low-skilled workers, are usually the more productive ones. Note, that the second mechanism cannot be the dominant one, as it would contradict the results of Section 6 on the KRATIO. The decline of low-skilled labor tends to raise the KRATIO. The fact that it declines with labor regulation indicates that there are additional mechanisms.

\section{Effects of Labor Regulation on R\&D}

The bias in adoption of high-skilled or low-skilled technologies should be reflected also in a similar bias in R\&D activity. In this section we test this implication with data on patent registration across countries and over time. The data is taken from the World Intellectual Property Organization, WIPO, see WIPO (2014). The taxonomy of patents by high and low-skilled follows Schmoch (2008). Our data therefore consist of numbers of high-skill patents and low-skill patents in a set of countries over many years. We have calculated for each country and each year the numbers of high- skill patents and low-skill patents per 1000 people. We denote these two variables by PAT_HS and PAT_LS. Actually we use in all the regressions below moving averages of patents over five years. The reason is that patent data reflect the end of rather long R\&D activities, and the ending time of such activity is itself random, which adds noise to the data. Hence, patent data might be more erratic than the underlying data on R\&D activity, which is the true data relevant to our analysis, but is unobservable. We overcome this problem by using moving averages. It is important to note that this point is not valid to the variables in the previous sections, KRATIO and productivities, which explains why we use such averaging only in this section.

The results of the regressions of these two variables on labor regulation are presented in Tables 5 and 6 below, which focus on high-skill patents and on low-skill patents respectively. In the two tables we add to the regressions also the total number of patents per capita in the country. The reason is that there are large differences between countries in their R\&D activity for various reasons. If we 
like to identify the bias toward high-skill and low-skill patenting we need to control for the overall R\&D activity. Since the total number of patents is highly correlated with the two variables PAT_HS and PAT_LS, we use instead of the current total patents per capita the lagged one year total patents per capita. The total patents are also averaged over 5 years and this variable is denoted PAT_L1.

[Insert Table 5 here]

Table 5 clearly shows that labor regulation has a negative effect on high skill patents in the economy. The results are very significant for employment protection legislation and for union density. Adding to the regression the minimum wage variable reduces significance of these variables and the variable MW_AW itself is insignificant. The results are quite similar both in the pooled and in the panel regressions with country fixed effects.

[Insert Table 6 here]

Table 6 presents the results of the regressions of low-skill patents on labor regulation and on total patents in a similar way to Table 5. Interestingly, Table 6 shows that labor regulation increases patents in low-skill sectors as the model predicts. The effects of EPL and UD on low-skill patents are positive and significant in all the pooled regression. In the panel regressions with country fixed effects only union density is significant, while employment protection legislation is insignificant. But the overall effect is quite clear. Countries with more stringent labor regulation tend to produce more patents for low skilled sectors than countries with low labor regulation. An examination of the size of the effect of EPL and UD on patent creation yields much smaller results than in Sections 6 and 7, but that is also because the variability in patent creation across countries is high for many other reasons. We know that there are very few countries that have a strong R\&D sector, and patent creation across countries is very unequal.

\section{Conclusions}

There is a vast literature on the question why countries differ technologically. While most of this literature focuses on differences between developed and less developed countries, this paper focuses instead on differences in technology between developed economies. The paper claims that such 
differences may arise between high and low skill sectors, and that they are a result of differences in labor market policies. Our model shows that labor market regulation changes the wage premium between high and low skilled and that affects the incentive to adopt technologies. This happens when technologies are embedded in machines that replace workers for specific jobs, or more generally in a model of 'labor cost induced technical change.' As a result countries with high labor regulation adopt more technologies in the low-skill sectors and less in the high-skill sectors, while countries with lower labor regulation have more technologies in the high-skill sector.

In the rest of the paper we examine various empirical implications of the model. We identify some measures of labor regulation and then we test how they affect technology adoption. The ratio of capital in the high and low skill sectors should fall with labor regulation in our model, while it should remain unchanged in a standard model without technical change. Indeed we show that the capital ratio falls significantly with the rise in labor regulation. Next we measure the productivities of high and low skill workers in each country and examine how they react to labor regulation, given that productivity and technology strongly related. We then turn to technology creation, which we expect to be correlated with technology use, although most countries adopt mostly technologies invented elsewhere, and the number of countries that innovate is quite small. The data on patents also indicate that countries with high labor regulation are less likely to innovate in the high skill sectors and more likely to innovate in low skill sectors. 


\section{Appendix}

\section{Derivation of the Goods Market Equilibrium Condition}

The first order condition for each intermediate good in the high-skill sector is:

$$
p_{s}(i)=P_{S} \frac{\partial S}{\partial s(i)}=\frac{P_{S} S}{s(i)} .
$$

Equating this demand price with the supply price in equation (8), deriving $s(i)$ and then substituting in the production function of the high-skill good (3) we get:

$$
\begin{aligned}
& \log S=a+\int_{0}^{1} \log \frac{P_{S} S}{p_{s}(i)} d i=a+\log S+\log P_{S}-\int_{0}^{f_{s}} \log \frac{R}{1-i} d i-\int_{f_{s}}^{1} \log w_{s} d i= \\
& =a+\log S+\log P_{S}-f_{s} \log R-\left(1-f_{s}\right) \log w_{s}+\int_{0}^{f_{s}} \log (1-i) d i .
\end{aligned}
$$

Due to (6) and $\int_{0}^{f_{s}} \log (1-i) d i=-\left(1-f_{s}\right) \log \left(1-f_{s}\right)-f_{s}$ the price of the high-skill good is equal to:

$$
\log P_{S}=f_{s}+\log R-a .
$$

In a similar way it is shown that the price of the low-skill good is

$$
\log P_{N}=f_{n}+\log R-a .
$$

While these prices reflect the supply side, from the demand side prices satisfy the following first order conditions:

$$
\begin{aligned}
& P_{S}=\frac{\partial Y}{\partial S}=\alpha S^{\alpha-1} N^{1-\alpha}=\frac{\alpha Y}{S}, \\
& P_{N}=\frac{\partial Y}{\partial N}=(1-\alpha) S^{\alpha} N^{\alpha}=\frac{(1-\alpha) Y}{N} .
\end{aligned}
$$

Substituting these first order conditions into the production function (2) we get the following constraint on the prices of the two goods:

$$
\alpha \log P_{S}+(1-\alpha) \log P_{N}=\varepsilon,
$$

where $\varepsilon$ denotes $\alpha \log \alpha+(1-\alpha) \log (1-\alpha)$. Substitute (A.2) and (A.3) in (A.4) and get:

$$
\alpha f_{s}+(1-\alpha) f_{n}=a+\varepsilon-\log R .
$$

This is the goods markets equilibrium condition. Note that this condition holds only if $f_{s}$ and $f_{n}$ are non-negative. Otherwise the derivation of equilibrium is slightly more complicated. 
2. Derivation of the Labor Market Equilibrium Conditions in the Benchmark Model

The supply of employed high-skill efficiency units is equal according to (15) to:

$$
\frac{L_{s}}{2}\left(1-\frac{v^{2}}{I^{2}}\right)
$$

The supply of low-skill efficiency units is equal according to (14) to:

$$
\frac{L_{n}}{2}\left(1-v^{2}\right)
$$

The demand for high-skill labor is equal to:

$$
\int_{f_{s}}^{1} s(i) d i=\int_{f_{s}}^{1} \frac{P_{S} S}{p_{s}(i)} d i=\left(1-f_{s}\right) \frac{\alpha Y}{w_{s}}=\frac{\alpha R Y}{w_{s}^{2}} .
$$

The demand for low-skill labor is equal to:

$$
\int_{f_{n}}^{1} n(i) d i=\int_{f_{n}}^{1} \frac{P_{N} N}{p_{n}(i)} d i=\left(1-f_{n}\right) \frac{(1-\alpha) Y}{w_{n}}=\frac{(1-\alpha) R Y}{w_{n}^{2}} .
$$

Equating the supplies and demands yields the equilibrium conditions (16) and (17).

\section{Calculation of the Effect of $v$ on $\operatorname{AVG}(U)$ at $v=0$ :}

Note first that from (24) we get:

$$
\operatorname{AVG}(U)=L_{n} v+L_{s} \frac{v}{I}+\ln w_{s}-L_{n} I+\ln (1-t)-1
$$

From equation (18), which describes the skill premium $I$, it follows, since $v$ is quadratic in this equation, that:

$$
\left.\frac{d I}{d v}\right|_{v=0}=0
$$

As a result the effect of $v$ on wages is also zero at this point. Note that from equation (21) we get that the tax rate is equal to:

$$
t=\frac{2 v^{2} w_{n}\left(L_{n}+L_{s} / I\right)}{L_{s} w_{s}\left(1+v^{2} / I^{2}\right)+L_{n} w_{n}\left(1+v^{2}\right)} .
$$

Since $v$ is quadratic in (A.6) and the wage variables are also unaffected by $v$ at $v=0$, we get that:

$$
\left.\frac{d t}{d v}\right|_{v=0}=0
$$


As a result we can now calculate the derivative of (A.5) at this point and get:

$$
\left.\frac{d \operatorname{AVG}(U)}{d v}\right|_{v=0}=L_{n}+\frac{L_{s}}{I}>0 .
$$

Hence, the effect of $v$ on welfare at 0 is positive.

\section{Capital Ratio and Labor Regulation in a Model without Technology Choice}

Assume a model similar to the paper with production in the high-skill sector described by:

$$
S=A_{S} K_{S}^{\beta} L_{S}^{1-\beta} .
$$

Similarly the low-skill good is produced by capital and low-skill labor:

$$
N=A_{N} K_{N}^{\beta} L_{N}^{1-\beta} .
$$

The equilibrium conditions in the capital market are:

$$
R=P_{S} A_{S} \beta K_{S}^{\beta-1} L_{S}^{1-\beta},
$$

and:

$$
R=P_{N} A_{N} \beta K_{N}^{\beta-1} L_{n}^{1-\beta} .
$$

First order conditions from profit optimization of production of the final product yield:

$$
\frac{P_{S}}{P_{N}}=\frac{\alpha}{1-\alpha} \frac{N}{S}
$$

From the Production functions in the two sectors and the two equilibrium conditions (A.7) and (A.8) we get:

$$
\frac{N}{S}=\frac{L_{N}}{L_{S}}\left(\frac{A_{N}}{A_{S}}\right)^{\frac{1}{1-\beta}}\left(\frac{P_{N}}{P_{S}}\right)^{\frac{\beta}{1-\beta}} .
$$

Combining (A.9) and (A.10) we get:

$$
1=\frac{\alpha}{1-\alpha} \frac{L_{N}}{L_{S}}\left(\frac{A_{N} P_{N}}{A_{S} P_{S}}\right)^{\frac{1}{1-\beta}} .
$$

From the equilibrium conditions (A.7) and (A.8) we derive the amounts of capital and find that the ratio of capital in the two sectors is:

$$
\frac{K_{S}}{K_{N}}=\frac{L_{S}}{L_{N}}\left(\frac{A_{S} P_{S}}{A_{N} P_{N}}\right)^{\frac{1}{1-\beta}} .
$$

Together with (A.11) we get: 


$$
\frac{K_{S}}{K_{N}}=\frac{\alpha}{1-\alpha}
$$

Hence, in a standard model, where technology cannot be changed, we get that the ratio of capital inputs in the two sectors does not depend on the wage premium and on labor regulation.

\section{Data Sources}

\begin{tabular}{|l|l|l|l|}
\hline Variable & Source & Time span & Countries \\
\hline EPL & $\begin{array}{l}\text { OECD Employment Protection Legislation } \\
\text { Database }\end{array}$ & $1985-2013$ & 44 \\
\hline UD and UC & $\begin{array}{l}\text { ICTWSS Institutional Characteristics of } \\
\text { Trade Unions, Wage Setting, State } \\
\text { Intervention and Social Pacts (Visser, 2011) }\end{array}$ & $1960-2011$ & 45 \\
\hline MW_AW & $\begin{array}{l}\text { I.L.O. International Labor Office Global } \\
\text { Wage Database }\end{array}$ & $1995-2011$ & 177 \\
\hline KRATIO & $\begin{array}{l}\text { Output, Input and Productivity Measures at } \\
\text { the Industry Level: the EU KLEMS } \\
\text { Database, O'Mahony and Timmer (2009) } \\
\text { ISIC 3 rev. March 2008 release }\end{array}$ & $1970-2005$ & 16 \\
\hline AS and AN & $\begin{array}{l}\text { Computed as in Caselli and Coleman (2006) } \\
\text { using Feenstra et al (2013), Barro and Lee } \\
\text { (2012) and Psacharoupolos (1994) data }\end{array}$ & $1950-2010$ & 52 \\
\hline HSPAT and LSPAT & $\begin{array}{l}\text { W.I.P.O. World Intellectual Property } \\
\text { Organization Database }\end{array}$ & $1980-2012$ & 100 \\
\hline
\end{tabular}

Table A.1: Data Sources and time/countries coverage 


\section{References}

Acemoglu, D. (1998), "Why Do new Technologies Complement Skills?" Quarterly Journal of Economics, 113 (1998), 1055-1089.

Acemoglu, D. (2003a), “Cross-Country Inequality Trends,” Economic Journal, 113, 121-149.

Acemoglu, D. (2003b), "Factor Prices and Technical Change: From Induced Innovations to Recent Debates," in Knowledge, Information and Expectations in Modern Macroeconomics: In Honor of Edmund Phelps, ed. by Philippe Aghion et al, Princeton University Press, Princeton NJ.

Acemoglu, D. and F. Zilibotti, (2001) "Productivity Differences," Quarterly Journal of Economics, $116,563-606$.

Alesina A, Y.Algan, P. Cahuc and P. Giuliano (2014) "Family Ties and the Regulation of Labor " Journal of the European Economic Association, (forthcoming).

Alesina A. S. Ardagna, G. Nicoletti and F. Schiantarelli (2005) "Regulation and Investment" Journal of the Euroepan Economic Association, 791-825

Alesina, A., and E. Glaeser (2004), Fighting Poverty in the U.S. and Europe: A World of Difference, Oxford University Press, Oxford, U.K.

Alesina, A., E. Glaeser, and B. Sacerdote (2005), "Work and Leisure in the U.S. and Europe: Why So Different?" NBER Macroeconomics Annual.

Autor D. W. Kerr and A. Kugler (2007) "Does employment protection reduce productivity? Evidence from US States" The Economic Journal, 117, June, 189-217

Autor D. F. Levy and R Murname (2003) "The Skill Content of Recent Technological Change: An Empirical Exploration" Quarterly Journal of Economics 1129-213.

Barro, Robert and Lee, Jong-Wha (2010), "A New Data Set of Educational Attainment in the World, 1950-2010," Journal of Development Economics, 104, 184-198.

Beaudry P. and F. Collard (2001) "Why has the Employment Productivity Trade off amongst Industrialized Countries so strong?" NBER Working Paper.

Bertrand M. and K Kramarz (2002) "Does Labor Regulation Hinder Job Creation? Evidence from the French Retail Industry? “ The Quatrely Journal of Economics, 117, 1369-1413.

Bjorklund, A., and R. B. Freeman (1997), "Generating Equality and Eliminating Poverty, the Swedish Way," in R. B. Freeman, R. Topel, and B. Swedenborg (eds.), The Welfare State in Transition: Reforming the Swedish Model, Chicago: University of Chicago Press, 33-78. 
Blanchard, O. J. (1997), “The Medium Run,” Brookings Papers on Economic Activity 2: 89-141.

Blanchard, O. J. (2004), “The economic future of Europe," Journal of Economic Perspectives, 18: 326

Blanchard, O. J., D. Cohen, and C. Nouveau (2005), "The history of French labor market institutions since 1950," unpublished.

Blanchard, O. J., and L. F. Katz (1999), "Wage Dynamics: Reconciling Theory and Evidence," American Economic Review 89: 69-74.

Blanchard, O. J., and J. Wolfers (2000), "The Role of Shocks and Institutions in the Rise of European Unemployment: The Aggregate Evidence," Economic Journal 110: 1-33.

Blau, F., and L. Kahn (1996a), "International Differences in Male Wage Inequality: Institutions versus Market Forces," Journal of Political Economy 104: 791-837.

Blau, F., and L. Kahn (1996b), "Wage Structure and Gender Earnings Differentials: An International Comparison," Economica 63: S29-62.

Blau, F., and L. Kahn (1999), "Institutions and Laws in the Labor Market," in O. C. Ashenfelter and D. Card (eds.), Handbook of Labor Economics, Amsterdam: Elsevier, 1399-1461.

Blau, F., and L. Kahn (2002), At Home and Abroad: U.S. labor markets in international perspective, Russell Sage, New York, NY.

Caballero, R., and M. Hammour (1998), "Jobless Growth: Appropriability, Factor Substitution and Unemployment," Carnegie-Rochester Conference Series on Public Policy, 48: 51-94.

Caselli, F., and Coleman, W. J. (2006). "The World Technology Frontier," American Economic Review, 96: 499-522.

Champernowne, D. (1963). "A Dynamic Growth Model Involving a Production Function," in F.A. Lutz and D.C. Hague, eds., The Theory of Capital New York: Macmillan, 1963

Comin, D. and B. Hobijn's (2004), "Cross-Country Technology Adoption: Making the Theories Face the Facts", Journal of Monetary Economics 51: 38-83.

Comin, D. and B. Hobijn (2009), "Lobbies and Technology Diffusion", The Review of Economics and Statistics, 91, 229-244.

Comin, Diego A., and Hobijn, Bart, “An Exploration of Technology Diffusion," American Economic Review, 100 (2010), 2031-2059.

Comin, Diego A., and Mestieri, Martí Ferrer, "If Technology Has Arrived Everywhere, Why Has Income Diverged?” NBER Working Paper No. 19010 (2013). 
Davis, S. J. and M. Henrekson, (1997), "Industrial Policy, Employer Size and Economic Performance in Sweden," in R. B. Freeman, R. Topel and B. Swedenborg (eds.), The Welfare State in Transition: Reforming the Swedish Model, Chicago: University of Chicago Press, 353-397.

Davis, S. J. and M. Henrekson, (1999), "Explaining National Differences in the Size and Industry Distribution of Employment, Small Business Economics, 12(1), 59-83.

Davis, S. J. and M. Henrekson, (2005a), "Wage-Setting Institutions as Industrial Policy," Labor Economics, 12(3), 345-377.

Davis, S. J. and M. Henrekson, (2005b), "Tax Effects on Work Activity, Industry Mix and Shadow Economy Size: Evidence from Rich-Country Comparisons," in R. Gómez-Salvador et al. (eds.), Labor Supply and Incentives to Work in Europe, Cheltenham, UK, Edward Elgar, 44-104.

Dornbusch, R. R. Gentilini, and F. Giavazzi (2000), "Italian Labor Force Participation: Disguised Unemployment on Campus," unpublished.

Edin, P.-A, and R. Topel (1997), "Wage Policy and Restructuring: The Swedish Labor Market since 1960," in R. B. Freeman, R. Topel and B. Swedenborg (eds.), The Welfare State in Transition: Reforming the Swedish Model, Chicago: University of Chicago Press, 155-201.

Feenstra, Robert C., Inklaar, Robert, and Timmer, Marcel P. (2013), "The Next Generation of the Penn World Table," Available at www.ggdc.net/pwt.

Freeman, R. B., and L. F. Katz, eds. (1995), Differences and Changes in Wages in Wage Structures, Chicago: University of Chicago Press.

Freeman, R. B., and R. Schettkat (2005), "Marketization of Household Production and the EU-US Gap in Work," Economic Policy, 1: 5-50.

Glyn A. J. Moeller, W. Salverda, J Scmitt, and M. Sollogoub (2007) "Employment Differences in Services: The Role of Wages Productivity and Demand" in M. Gregory and W. Salverda and R. Schettkat (es) Service Included? Services and the European-American Employment Gap, forthcoming Cambridge University Press Cambridge UK.

Gottschalk, P., and T. Smeeding (1997), "Cross National Comparisons of Earnings and Income Inequality,” Journal of Economic Literature, 35: 633-87.

ILO (2013), Global Wage Dataset.

Kahn, L. M. (1998a), "Against the Wind: Bargaining Recentralization and Wage Inequality in Norway, 1987-1991," Economic Journal 108: 603-45.

Kahn, L. M. (1998b), "Collective Bargaining and the Inter-industry Wage Structure: International Evidence," Economica 65: 507-34. 
Kahn, L. M. (2000), “Wage Inequality, Collective Bargaining, and Relative Employment, 1985-94: Evidence from 15 OECD Countries," Review of Economics and Statistics 82: 564-79.

Katz, L. F., and K. M. Murphy (1992), “Changes in Relative Wages, 1963-1987: Supply and Demand Factors," Quarterly Journal of Economics 107: 35-78.

Koeniger, Winfried, and Marco Leonardi (2007), "Capital Deepening and Wage Differentials: Germany versus US," Economic Policy, , 3-46.

Kramarz, F. (2007), “Outsourcing, Unions, Wages, and Employment: Evidence from Data Matching Imports, Firms and Workers," mimeo.

Lazear, E. P. (1990), "Job Security, Provisions and Employment," Quarterly Journal of Economics, 105: 699-726.

Lewis, E. (2005), "Immigration, Skill Mix, and the Choice of Technique," Federal Reserve Bank of Philadelphia Working Paper.

Ngai, R. L., and C. A. Pissarides (2009), "Welfare Policy and the Sectoral Distribution of Employment," Discussion Paper No. 09/04, Center for Structural Econometrics.

Nickell S. (1997) “Unemployment and Labor Market Rigidities” Journal of Economic Perspectives, 11(55-74).

Nickell S. and R. Layard (1999) "Labor Market Institutions and Economic Performance" in O. Ashenfelter and D. Card (eds) Handbook of Labor Economics Volume $3 b$ North Holland Amsterdam.

OECD (2013), Employment Protection Database, 2013 Update.

O'Mahony, Mary and Timmer, Marcel P. (2009), "Output, Input and Productivity Measures at the Industry Level: The EU KLEMS Database,” Economic Journal, 119, F374-F403.

O’Mahony, M. and B. van Ark (2003), eds., EU Productivity and Competitiveness: An Industry Perspective Can Europe Resume the Catching-up Process? Office for Official Publications of the European Communities, Luxembourg.

Parente, S.L., and E. Prescott, "Barrier to Technology Adoption and Development," Journal of Political Economy, 102 (1994), 298-321.

Prescott, E. (2004), "Why Do Americans Work So Much More than Europeans?" Federal Reserve Bank of Minneapolis Quarterly Review, 28: 2-13.

Psacharopoulos, G. (1994), Returns to Investment in Education: A Global Update, World Development, Vol. 22, No 9, pp. 132.5-1 343. 
Robinson, Catherine, Stokes, Lucy, Stuivenwold, Edwin, and van Ark, Bart, (2003), "Chapter II: Industry Structure and Taxonomies," in EU Productivity and Competitiveness: An Industry Perspective Can Europe Resume the Catching-up Process? Eds. O’Mahony, Mary. and van Ark, Bart, Office for Official Publications of the European Communities, Luxembourg, 37-71.

Rogerson R. (2007) "Structural Transformations and the Deterioration of European Employment Outcome," Journal of Political Economy, 116, 235-259.

Rogerson, R. and J. Wallenius (2007), "Micro and Macro Elasticities in a Life Cycle Model with Taxes," Journal of Economic Theory, 144, 2277-2292.

Saint-Paul, Gilles (2004), "Why are European Countries Diverging in their Unemployment Experience?” Journal of Economic Perspectives, 18, 49-68.

Saint-Paul G. (2006) "Distribution and Growth in an Economy with Limited Needs: Variable Markups and the 'End of Work"' Economic Journal, 116, 382-407.

Schmoch, Ulrich, (2008), "Concept of a Technology Classification for Country Comparisons," Report to the World Intellectual Property Organization (WIPO).

Shapiro, Carl, and Stiglitz, Joseph E. (1984), "Equilibrium Unemployment as a Worker Discipline Device," The American Economic Review, 74, 433-444.

Zeira, J. (1998), “Workers, Machines and Economic Growth,” Quarterly Journal of Economics, 113, 1091-1113.

Zeira, J. (2007), “Machines as engines of growth,” unpublished.

Zuleta, H. (2006), "Why Factor Income Shares Seem to be Constant?” The Journal of Trade \& Economic Development, 16, 551-557. 


\section{Tables}

\begin{tabular}{|l|c|c|c|c|}
\hline Variable & EPL & UD & UC & MW_AW \\
\hline No. of Observations & 846 & 1342 & 1312 & 1081 \\
\hline Mean & 2.20 & 39.42 & 60.92 & 0.39 \\
\hline Standard Deviation & 0.84 & 22.6 & 27.88 & 0.19 \\
\hline Minimum & .26 & 5.8 & 1 & 0.0002 \\
\hline Maximum & 5 & 99.1 & 100 & 0.997 \\
\hline Correlation with EPR & 1.00 & 0.06 & 0.48 & -0.16 \\
\hline Correlation with UD & 0.06 & 1.00 & 0.54 & 0.13 \\
\hline Correlation with MW_AW & -0.16 & 0.13 & 0.24 & 1.00 \\
\hline
\end{tabular}

Table 1: Descriptive Statistics of Measures of Labor Regulation 


\begin{tabular}{|l|c|c|c|c|c|c|}
\hline \multicolumn{7}{|c|}{ Dependent Variable: $\Delta$ KRATIO } \\
\hline Explanatory Variables & \multicolumn{2}{|c|}{ Pooled Regressions } & \multicolumn{2}{c|}{ Panel Fixed Effects Regressions } \\
\hline EPL & $\mathbf{1}$ & $\mathbf{2}$ & $\mathbf{3}$ & $\mathbf{4}$ & $\mathbf{5}$ & $\mathbf{6}$ \\
\hline & $-0.008^{* * *}$ & $-0.006^{* *}$ & 0.001 & $-0.074^{* * *}$ & $-0.079^{* * *}$ & $-0.103^{* * *}$ \\
& $(0.003)$ & $(0.003)$ & $(0.03)$ & $(0.022)$ & $(0.023)$ & $(0.028)$ \\
\hline UD & & $-0.063^{* * *}$ & $-0.296^{* * *}$ & & $-0.113^{*}$ & 0.216 \\
& & $(0.016)$ & $(0.050)$ & & $(0.062)$ & $(0.208)$ \\
\hline MW_AW & & & $0.114^{* * *}$ & & & -0.298 \\
& & & $(0.034)$ & & & $(0.181)$ \\
\hline DUMMY 1991 & 0.024 & 0.015 & & $0.043^{*}$ & 0.036 & \\
\hline Constant & $(0.04)$ & $(0.039)$ & & $(0.022)$ & $(0.022)$ & \\
\hline $\mathrm{R}^{2}$ & $0.030^{* * *}$ & $0.050^{* * *}$ & $0.041^{* *}$ & $0.170^{* * *}$ & $0.170^{* * *}$ & $0.307^{* * *}$ \\
\hline $\mathrm{R}^{2}$ (within) & $(0.006)$ & $(0.007)$ & $(0.17)$ & $(0.048)$ & $(0.048)$ & $(0.111)$ \\
\hline No. of Observation & 0.02 & 0.075 & 0.263 & & & \\
\hline No. of Countries & 278 & 278 & 77 & 278 & 278 & 77 \\
\hline 1. All standard errors are robust. & 15 & 15 & 9 & 15 & 15 & 9 \\
\hline 3. All regressions include country fixed effects. & & & & \\
\hline
\end{tabular}

Table 2: Effects of Labor Regulation on Changes in Ratio of Capital 


\begin{tabular}{|c|c|c|c|c|c|c|c|}
\hline & \multicolumn{7}{|c|}{ Dependent Variable: $\ln (\mathrm{AS})$} \\
\hline $\begin{array}{l}\text { Explanatory } \\
\text { Variables }\end{array}$ & 1 & 2 & 3 & 4 & 5 & 6 & 7 \\
\hline EPL & $\begin{array}{c}-0.243 * * * \\
(0.05)\end{array}$ & $\begin{array}{c}-0.130 * * * \\
(0.043)\end{array}$ & $\begin{array}{c}-0.431 * * * \\
(0.04)\end{array}$ & $\begin{array}{c}-0.396^{* * *} \\
(0.03)\end{array}$ & $\begin{array}{c}-0.421 * * * \\
(0.03)\end{array}$ & $\begin{array}{c}-0.274 * * * \\
(0.03)\end{array}$ & $\begin{array}{c}0.186^{* * * *} \\
(0.06)\end{array}$ \\
\hline UD & & & & $\begin{array}{c}-1.801 * * * \\
(0.10)\end{array}$ & $\begin{array}{c}-1.775^{* * *} \\
(0.14)\end{array}$ & $\begin{array}{c}-0.577^{* * *} \\
(0.18)\end{array}$ & $\begin{array}{c}0.954^{*} \\
(0.49)\end{array}$ \\
\hline $\mathrm{UC}$ & & & & & $\begin{array}{l}-0.110 \\
(0.13)\end{array}$ & $\begin{array}{l}-0.085 \\
(0.117)\end{array}$ & $\begin{array}{c}-1.102 * * * \\
(0.313)\end{array}$ \\
\hline MW_AW & & & & & & & $\begin{array}{c}0.395^{*} \\
(0.23)\end{array}$ \\
\hline Trend & & & & & & $\begin{array}{c}0.011 * * * \\
(0.001)\end{array}$ & $\begin{array}{c}0.009 * * * \\
(0.002)\end{array}$ \\
\hline Constant & $\begin{array}{c}5.765^{* * *} \\
(0.10)\end{array}$ & $\begin{array}{c}5.682 * * * \\
(0.10)\end{array}$ & $\begin{array}{c}6.350^{* * *} \\
(0.10)\end{array}$ & $\begin{array}{c}6.885 * * * \\
(0.08)\end{array}$ & $\begin{array}{c}7.073 * * * \\
(0.11)\end{array}$ & $\begin{array}{c}5.784 * * * \\
(0.167)\end{array}$ & $\begin{array}{c}4.709 * * * \\
(0.28)\end{array}$ \\
\hline $\mathrm{R}^{2}$ & 0.169 & 0.07 & & & & & \\
\hline $\mathrm{R}^{2}$ (within) & & & 0.15 & 0.49 & 0.48 & 0.57 & 0.41 \\
\hline Fixed Effects & $\mathrm{NO}$ & $\mathrm{NO}$ & YES & YES & YES & YES & YES \\
\hline Extended & NO & YES & YES & YES & YES & YES & YES \\
\hline Observations & 104 & 578 & 578 & 556 & 495 & 495 & 163 \\
\hline Countries & 23 & 23 & 23 & 22 & 22 & 22 & 14 \\
\hline
\end{tabular}

Table 3: Effects of Labor Regulation on Productivity of High-Skilled Labor 


\begin{tabular}{|c|c|c|c|c|c|c|c|}
\hline & \multicolumn{7}{|c|}{ Dependent Variable: $\ln (\mathrm{AN})$} \\
\hline $\begin{array}{l}\text { Explanatory } \\
\text { Variables }\end{array}$ & 1 & 2 & 3 & 4 & 5 & 6 & 7 \\
\hline EPL & $\begin{array}{c}1.028 * * * \\
(0.18)\end{array}$ & $\begin{array}{c}1.196^{* * *} \\
(0.09)\end{array}$ & $\begin{array}{c}1.102 * * * \\
(0.08)\end{array}$ & $\begin{array}{c}2.574 * * * \\
(0.64)\end{array}$ & $\begin{array}{c}2.329 * * * \\
(0.61)\end{array}$ & $\begin{array}{c}2.399 * * * \\
(0.73)\end{array}$ & $\begin{array}{c}0.049 \\
(0.776)\end{array}$ \\
\hline UD & & & & & $\begin{array}{c}1.513 * * * \\
(0.19)\end{array}$ & $\begin{array}{c}1.749 * * * \\
(0.31)\end{array}$ & $\begin{array}{l}-1.689 \\
(4.010)\end{array}$ \\
\hline $\mathrm{UC}$ & & & & & & $\begin{array}{l}-2.248 \\
(2.759)\end{array}$ & $\begin{array}{l}-2.653 \\
(2.630)\end{array}$ \\
\hline Trend & & & $\begin{array}{c}-0.160 * * * \\
(0.08)\end{array}$ & & & & $\begin{array}{c}-0.174^{* * *} \\
(0.025)\end{array}$ \\
\hline Constant & $\begin{array}{c}-3.991 * * * \\
(0.50)\end{array}$ & $\begin{array}{c}-4.273^{\text {*** }} \\
(0.253)\end{array}$ & $\begin{array}{c}3.839 * * * \\
(1.02)\end{array}$ & $\begin{array}{l}7.340^{* * *} \\
(1.424)\end{array}$ & $\begin{array}{c}11.826^{* * * *} \\
(1.74)\end{array}$ & $\begin{array}{c}-11.555 * * * \\
(2.43)\end{array}$ & $\begin{array}{l}9.073^{* *} \\
(3.759)\end{array}$ \\
\hline $\mathrm{R}^{2}$ & 0.164 & 0.09 & 0.22 & & & & \\
\hline $\mathrm{R}^{2}$ (within) & & & & 0.03 & 0.13 & 0.11 & 0.19 \\
\hline Fixed Effects & $\mathrm{NO}$ & $\mathrm{NO}$ & $\mathrm{NO}$ & YES & YES & YES & YES \\
\hline Extended & $\mathrm{NO}$ & YES & YES & YES & YES & YES & YES \\
\hline Observations & 104 & 578 & 578 & 578 & 556 & 495 & 495 \\
\hline Countries & 23 & 23 & 23 & 23 & 22 & 22 & 22 \\
\hline
\end{tabular}

Table 4: Effects of Labor Regulation on Productivity of Low-Skilled Labor 


\begin{tabular}{|c|c|c|c|c|c|c|}
\hline \multirow{3}{*}{$\begin{array}{l}\text { Explanatory } \\
\text { Variable }\end{array}$} & \multicolumn{6}{|c|}{ Dependent Variable: PAT_HS } \\
\hline & \multicolumn{3}{|c|}{ Pooled Regressions } & \multicolumn{3}{|c|}{ Fixed Effects Regressions } \\
\hline & 1 & 2 & 3 & 4 & 5 & 6 \\
\hline PAT_L1 & $\begin{array}{c}0.681 * * * \\
(0.01)\end{array}$ & $\begin{array}{c}0.684 * * * \\
(0.01)\end{array}$ & $\begin{array}{c}0.698 * * * \\
(0.01)\end{array}$ & $\begin{array}{c}0.697 * * * \\
(0.01)\end{array}$ & $\begin{array}{c}0.708 * * * \\
(0.01)\end{array}$ & $\begin{array}{c}0.719 * * * \\
(0.01)\end{array}$ \\
\hline EPL & $\begin{array}{c}-0.008 * * * \\
(0.003)\end{array}$ & $\begin{array}{c}-0.007 * * \\
(0.003)\end{array}$ & $\begin{array}{l}-0.006 \\
(0.004)\end{array}$ & $\begin{array}{c}-0.029 * * * \\
(0.01)\end{array}$ & $\begin{array}{c}-0.035^{* * *} \\
(0.01)\end{array}$ & $\begin{array}{c}-0.062 * \\
(0.04)\end{array}$ \\
\hline UD & & $\begin{array}{c}-0.001 * * * \\
(0.000)\end{array}$ & $\begin{array}{c}-0.001 * * * \\
(0.000)\end{array}$ & & $\begin{array}{c}-0.0004 \\
(0.0003)\end{array}$ & $\begin{array}{c}0.001 \\
(0.001)\end{array}$ \\
\hline MW_AW & & & $\begin{array}{l}-0.055 \\
(0.05)\end{array}$ & & & $\begin{array}{l}0.004 \\
(0.17)\end{array}$ \\
\hline Constant & $\begin{array}{c}-0.008 \\
(0.009)\end{array}$ & $\begin{array}{c}0.021 * * * \\
(0.009)\end{array}$ & $\begin{array}{c}0.060 * * * \\
(0.02)\end{array}$ & $\begin{array}{l}0.030 \\
(0.02)\end{array}$ & $\begin{array}{c}0.047^{*} \\
(0.03)\end{array}$ & $\begin{array}{l}0.086 \\
(0.12)\end{array}$ \\
\hline $\mathrm{R}^{2}$ & 0.97 & 0.97 & 0.98 & & & \\
\hline $\mathrm{R}^{2}$ (within) & & & & 0.94 & 0.94 & 0.93 \\
\hline Obs. & 835 & 701 & 273 & 835 & 701 & 273 \\
\hline Countries & 42 & 36 & 27 & 42 & 36 & 27 \\
\hline
\end{tabular}

Table 5: Effects of Labor Regulation on High-Skill Patents per Capita 


\begin{tabular}{|c|c|c|c|c|c|c|}
\hline \multirow{3}{*}{$\begin{array}{l}\text { Explanatory } \\
\text { Variable } \\
\end{array}$} & \multicolumn{6}{|c|}{ Dependent Variable: PAT_LS } \\
\hline & \multicolumn{3}{|c|}{ Pooled Regressions } & \multicolumn{3}{|c|}{ Fixed Effects Regressions } \\
\hline & 1 & 2 & 3 & 4 & 5 & 6 \\
\hline PAT_L1 & $\begin{array}{c}0.330 * * * \\
(0.005)\end{array}$ & $\begin{array}{c}0.333 * * * \\
(0.006)\end{array}$ & $\begin{array}{c}0.321 * * * \\
(0.01)\end{array}$ & $\begin{array}{c}0.271 * * * \\
(0.003)\end{array}$ & $\begin{array}{c}0.274 * * * \\
(0.004)\end{array}$ & $\begin{array}{c}0.249 * * * \\
(0.006)\end{array}$ \\
\hline EPL & $\begin{array}{c}0.007 * * * \\
(0.002)\end{array}$ & $\begin{array}{c}0.006^{* * *} \\
(0.002)\end{array}$ & $\begin{array}{l}0.005^{*} \\
(0.003)\end{array}$ & $\begin{array}{c}0.008 \\
(0.006)\end{array}$ & $\begin{array}{c}0.009 \\
(0.007)\end{array}$ & $\begin{array}{c}-0.034^{* *} \\
(0.02)\end{array}$ \\
\hline UD & & $\begin{array}{c}0.0004 * * * \\
(0.0001)\end{array}$ & $\begin{array}{c}0.0004 * * \\
(0.0002)\end{array}$ & & $\begin{array}{c}0.098 * * * \\
(0.019)\end{array}$ & $\begin{array}{c}0.183 * * * \\
(0.061)\end{array}$ \\
\hline MW_AW & & & $\begin{array}{l}0.002 \\
(0.02)\end{array}$ & & & $\begin{array}{l}-0.068 \\
(0.07)\end{array}$ \\
\hline Constant & $\begin{array}{c}0.001 \\
(0.006)\end{array}$ & $\begin{array}{l}-0.009 * \\
(0.006)\end{array}$ & $\begin{array}{l}-0.016 \\
(0.013)\end{array}$ & $\begin{array}{c}0.030 * * \\
(0.01)\end{array}$ & $\begin{array}{l}0.001 \\
(0.02)\end{array}$ & $\begin{array}{c}0.107 * * \\
(0.05)\end{array}$ \\
\hline $\mathrm{R}^{2}$ & 0.94 & 0.95 & 0.97 & & & \\
\hline $\mathrm{R}^{2}$ (within) & & & & 0.88 & 0.88 & 0.90 \\
\hline Obs. & 835 & 701 & 273 & 835 & 701 & 273 \\
\hline Countries & 42 & 36 & 27 & 42 & 36 & 27 \\
\hline
\end{tabular}

Table 6: Effects of Labor Regulation on Low-Skill Patents per Capita 